\title{
Actions of isosorbide dinitrate on smooth muscle cells of rabbit vascular tissues
}

\author{
S. Ishikawa, Y. Ito, T. Itoh, Y. Kanmura, H. Kuriyama \& Y. Makita \\ Department of Pharmacology, Faculty of Medicine, Kyushu University, Fukuoka 812, Japan
}

1 To investigate the mechanism of the anti-anginal actions of isosorbide dinitrate (ISDN), the effects of this agent on smooth muscle cells of intact and skinned preparations of the rabbit mesenteric artery and vein, and of the coronary artery were studied.

2 ISDN $\left(<10^{-5} \mathrm{M}\right)$ had no effect on the membrane potential or resistance of smooth muscle cells of the mesenteric artery and vein under resting conditions, nor when the membrane was depolarized by the presence of various concentrations of $[\mathrm{K}]_{\mathrm{o}}$ or noradrenaline (NA). The amplitude of spike evoked by outward current pulse after pretreatment with $10 \mathrm{mM}$ tetraethylammonium (TEA) in the mesenteric artery was slightly inhibited by application of $10^{-5} \mathrm{M}$ ISDN.

3 The $\mathrm{K}$-induced and NA-induced contractions in the mesenteric artery were not affected by $10^{-5} \mathrm{M}$ ISDN, while those evoked in the mesenteric vein were inhibited in concentrations above $10^{-6} \mathrm{M}$.

4 The amplitude and facilitation of excitatory junction potentials evoked by perivascular nerve stimulation in the mesenteric artery were not affected by $10^{-5} \mathrm{M}$ ISDN.

5 In skinned muscles, the free calcium concentration ( $\mathrm{pCa}$ )-tension relationships observed in the mesenteric artery and vein were not affected by $10^{-5} \mathrm{M}$ ISDN. This agent had no effect on Ca accumulation into and $\mathrm{Ca}$ release from the stores in muscle cells of the mesenteric artery and vein, in skinned preparations.

6 In the rabbit coronary artery, the membrane potential, resistance and spike evoked in the presence of $10 \mathrm{mM}$ TEA were not affected by application of $10^{-5} \mathrm{M}$ ISDN. The contraction evoked by excess concentrations of $[\mathrm{K}]_{\mathrm{o}}$ was not affected. The contraction evoked by a low concentration of acetylcholine $\left(3 \times 10^{-7} \mathrm{M}\right)$ but by high concentrations $\left(>10^{-6} \mathrm{M}\right)$ was slightly inhibited by $10^{-5} \mathrm{M}$ ISDN. A tonic contraction induced in $39 \mathrm{mM}[\mathrm{K}]_{0}$ was reduced by $10^{-5} \mathrm{M}$ nitroglycerine but not by $10^{-5} \mathrm{M}$ ISDN.

7 Thus in rabbit vascular tissues, ISDN mainly acts on the venous system in vitro. The induced vasodilatation may lead to a reduction in the venous return and hence, reduce oxygen consumption in the cardiac muscles. This effect of ISDN may relate to the anti-anginal actions.

\section{Introduction}

Glyceryl trinitrate (nitroglycerine), isosorbide dinitrate and other alkylnitrates have been reported to increase the coronary blood flow by decreasing the resistance of the coronary bed through direct vasodilatation (Brunton, 1867; Murrell, 1879; Goldberg, 1948). These agents also reduce the venous return and hence, reduce the central blood pressure and the left ventricular end-diastolic pressure. The oxygen requirements in the myocardium are thereby diminished and the myocardial ischaemia relieved (Parker, 1972; Needleman \& Johnson, 1973; Parratt, 1974; 1975; Vatner \& Heyndrickx, 1975; Krantz, 1975).
Mackenzie \& Parratt (1977) observed that in isolated vessels, both nitroglycerine and sodium nitrate relax venous smooth muscles in veins more than arteries, particularly when these tissues are contracted with noradrenaline (NA). Therefore, nitrate compounds may possess a regional specificity, as related to the induced vasodilatation.

Isosorbide dinitrate (ISDN) is a long-acting nitrate similar to nitroglycerine with regard to relief of anginal pain and myocardial ischaemia (Krantz, 1975).

The present experiments were carried out to investigate the mechanism of the anti-anginal action of ISDN on vascular tissues. The membrane properties 
of single cells and mechanical properties of small intact and skinned muscle preparations of coronary artery, and mesenteric artery and vein were investigated. The results indicate that ISDN acts mainly on the venous system in vitro, thereby reducing oxygen consumption by the cardiac muscles and hence providing protection for ischaemic cardiac muscle tissues.

\section{Methods}

Albino rabbits of either sex $(2-3 \mathrm{~kg})$ were anaesthetized with sodium barbitone $40 \mathrm{mg} / \mathrm{kg}$ intravenously and then exsanguinated. The mesentery of the jejunum was removed and immediately placed in a dissecting chamber filled with Krebs solution. The mesenteric artery and vein were excised under a binocular microscope. The diameter of the vessels was $0.2-0.3 \mathrm{~mm}$. The main coronary artery was also excised using the same procedures and its diameter was $0.8-1.1 \mathrm{~mm}$.

The ionic composition of the Krebs solution was as follows (mM): $\mathrm{Na}^{+} 137.4, \mathrm{~K}^{+} 5.9, \mathrm{Mg}^{2+} 1.2, \mathrm{Ca}^{2+} 2.5$, $\mathrm{HCO}_{3}{ }^{-15.5}, \mathrm{H}_{2} \mathrm{PO}_{4}{ }^{-} 1.2, \mathrm{Cl}^{-} 134$ and glucose 11.5 . High- $[\mathrm{K}]_{\mathrm{o}}$ solution was prepared by replacing $\mathrm{NaCl}$ with $\mathrm{KCl}$, isosmotically.

\section{Recording of electrical activity}

In the microelectrode experiments, the intact mesenteric artery or vein, or helically cut coronary artery $(0.2-0.3 \mathrm{~mm}$ in width and $5 \mathrm{~mm}$ in length) was mounted in an organ bath with a capacity of about $2 \mathrm{ml}$ and $\mathrm{Krebs}$ solution $\left(34-35^{\circ} \mathrm{C}\right)$ was superfused at a flow rate of about $3 \mathrm{ml} \mathrm{min}^{-1}$.

For stimulation of the muscle or perivascular nerves, the partition stimulating method was used (Abe \& Tomita, 1968). For muscle stimulation, a $1-2 \mathrm{~s}$ current pulse was applied to the long axis of the mesenteric artery or vein, and for nerve stimulation, a pulse $0.05-0.1 \mathrm{~ms}$ in duration was applied. A glass capillary microelectrode (Hilgenberg Glass, Frankfurt) filled with $3 \mathrm{M} \mathrm{KCl}$ and with a tip resistance of $40-80 \mathrm{M} \Omega$ was used to impale single cells and the electrical activities of the muscle membrane were recorded (Nihon Kohden Recticorder; RJG (4024) Tokyo).

The double sucrose-gap method was used to measure simultaneously the membrane potential and tension development. The apparatus for measurements of electrical and mechanical properties were similar to those described by Ito, Kitamura \& Kuriyama (1979). Strips of porcine coronary artery were prepared $(0.5 \mathrm{~mm}$ wide and 5 to $6 \mathrm{~mm}$ in length) for experiments using the double sucrose-gap method.
In such preparations, the precise value of the membrane potential could not be measured (in the porcine coronary artery, the membrane potential was $-50 \mathrm{mV}$ measured by the microelectrode method and $-41 \mathrm{mV}$ by the double sucrose-gap method, see results), but the relationship between the membrane potential (application of $1.5-2 \mathrm{~s}$ pulse) and contraction could be obtained. The resting tension of the tissue was kept below $0.05 \mathrm{~g}$.

\section{Recording of mechanical activity}

Mechanical responses of the mesenteric artery and vein evoked by high concentrations of $[\mathrm{K}]_{\mathrm{o}}$ or NA were measured. One end of a circular cut strip from the mesenteric artery or vein $(0.08-0.1 \mathrm{~mm}$ in width and $0.3 \mathrm{~mm}$ in length) was connected to a strain gauge (U-gauge, Shinko Seiki, Tokyo). The tissue was superfused in an organ bath $(0.9 \mathrm{ml})$ with Krebs solution. The same procedures were adopted for the porcine coronary artery. Solutions containing drugs or with modified ionic concentrations were added to the bath after the bathing solution had been siphoned off; therefore, the test solutions could be changed in a few seconds. However, this procedure was accompanied by large artifacts due to sudden changes in the level of the solution in the organ bath. To rule out such artifacts, recovery of the position of the recording pen to the original level was checked prior to the experiment, and the recording systems were appropriately adjusted (Itoh, Kuriyama \& Suzuki, 1981). Mechanical responses of the mesenteric artery or vein $(0.2-0.3 \mathrm{~mm}$ in width and $0.5-0.6 \mathrm{~mm}$ in length in circularly cut preparation) evoked by direct muscle stimulation ( $50 \mathrm{~ms}$ pulse duration) were measured using a strain gauge, after pretreatment with $10^{-7} \mathrm{M}$ tetrodotoxin (TTX) and $10^{-6} \mathrm{M}$ guanethidine. The mechanical response to perivascular nerve stimulation ( $0.55 \mathrm{~ms}$ pulse duration) was recorded, electrical stimulation of the nerves was provided by two silver plates (coated with $\mathrm{Ag}-\mathrm{AgCl}$ ) placed in parallel with the strip in the organ bath.

Skinned muscle preparations were obtained by using saponin, according to the method described by Itoh et al., (1981). After a K-induced contraction of the intact muscle had been recorded, the bathing solution was replaced with a relaxant solution containing (mM): $\mathrm{KCl} 130$, Tris-maleate $20, \mathrm{MgCl}_{2} 5$, ATP 5 (Na 10 as $\mathrm{Na}_{2}$-ATP) and EGTA 4 at pH 6.8 . The preparation was left for $20 \mathrm{~min}$ in the relaxant solution containing $50 \mu \mathrm{g} / \mathrm{ml}$ saponin (ICN) and was washed again with the same solution and left until a low constant resting tension was achieved. To investigate the effects of ISDN on the calmodilin or contractile proteins, the $\mathrm{Ca}$-tension curve in the presence or absence of ISDN was observed. Various Ca concentrations were prepared by adding appropriate 

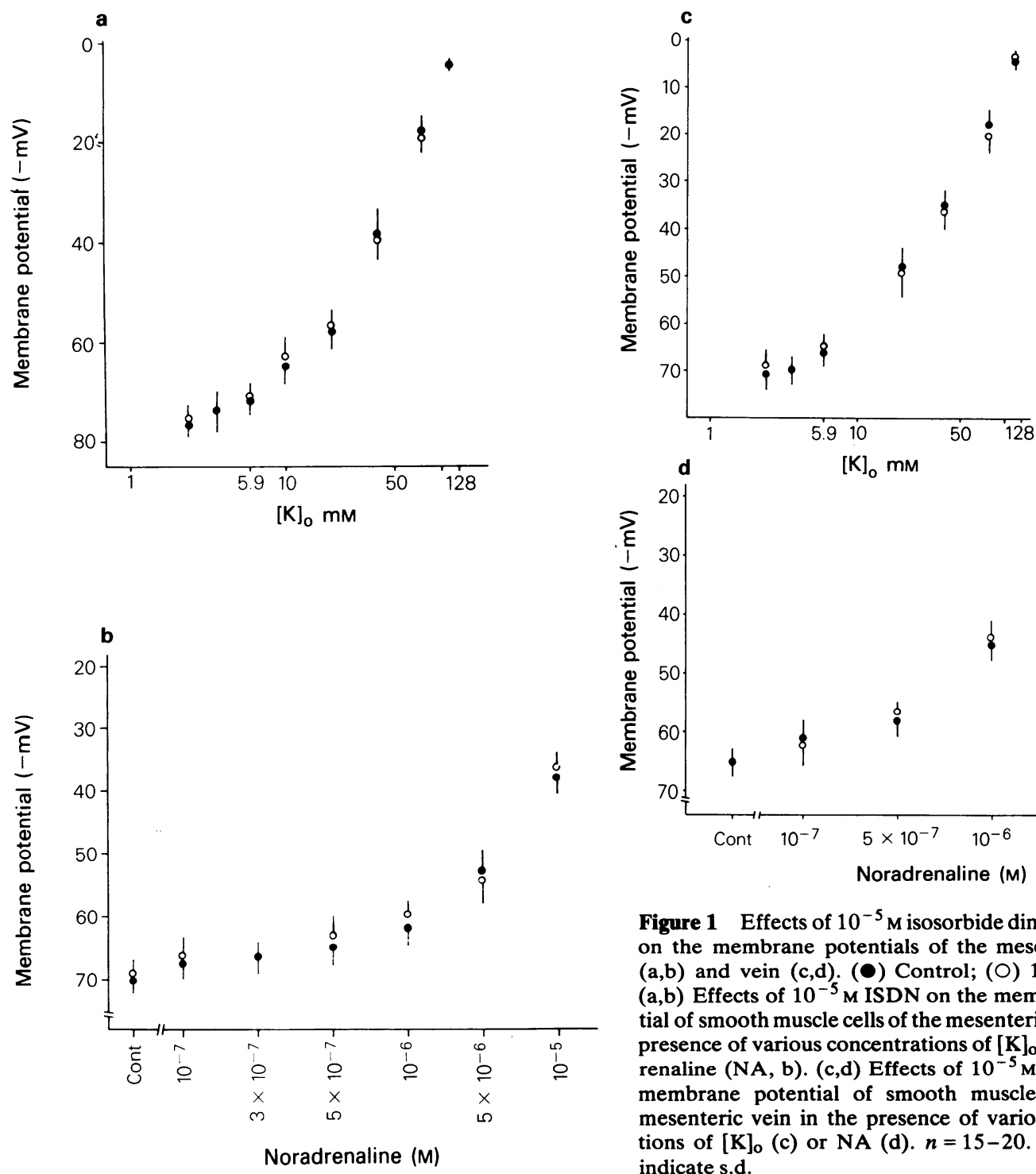

amounts of $\mathrm{CaCl}_{2}$ to EGTA. The apparent binding constant of EGTA for Ca was taken to be $10^{6} \mathrm{M}^{-1}$ at pH 6.8 and $25^{\circ} \mathrm{C}$ (Itoh et al., 1981). The pH of the relaxant and various $\mathrm{Ca}$ solutions was kept at 6.8 by adding $\mathrm{KOH}$ instead of $\mathrm{KCl}$, isotonically.

\section{Drugs}

Chemicals used in the experiments were isosorbide dinitrate (ISDN, Eisai Pharmac.); atropine sulphate (E. Merck); caffeine (Wako Pharmac.); saponin (ICN Pharmaco.); noradrenaline-HCl (NA;

Sigma); acetylcholine-Cl (Daiichi Pharmac.); guanethidine (Tokyo Kasei); tetraethylammoniumCl (TEA; Tokyo Kasei); tetrodotoxin (TTX; Sigma); nitroglycerine (water soluble type. Nihon Kayaku) and ethyleneglycolbis ( $\beta$-aminoethylether)-N,N'tetraacetic acid (EGTA; Dozin Lab.).

\section{Statistics}

The - results obtained were expressed as the mean value \pm s.d. (number of tests), and the statistical sig-

nificance was assessed by Student's $t$-test.

Figure 1 Effects of $10^{-5} \mathrm{M}$ isosorbide dinitrate (ISDN) on the membrane potentials of the mesenteric artery $(\mathrm{a}, \mathrm{b})$ and vein $(\mathrm{c}, \mathrm{d})$. (O) Control; (O) $10^{-5} \mathrm{M}$ ISDN. (a,b) Effects of $10^{-5} \mathrm{M}$ ISDN on the membrane potenof smooth muscle cells of the mesenteric artery in the presence of various concentrations of $[K]_{0}(a)$ or noradmembrane potential of smooth muscle cells of the mesenteric vein in the presence of various concentrations of $[\mathrm{K}]_{\mathrm{o}}$ (c) or NA (d). $n=15-20$. Vertical bars indicate s.d. 


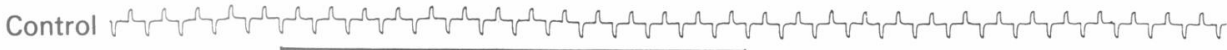

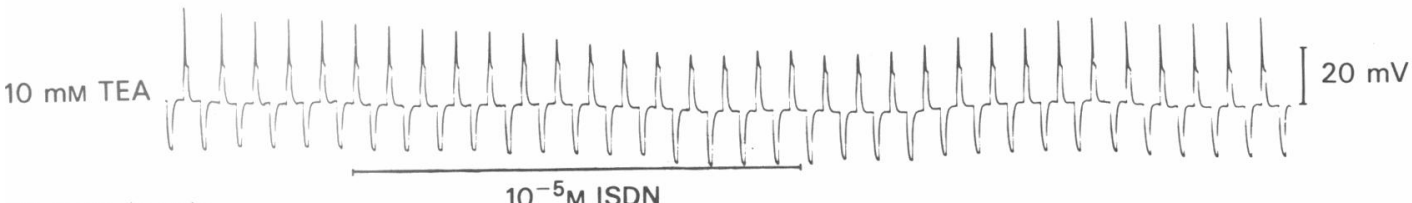

Mesenteric vein

$10^{-5} \mathrm{M}$ ISDN

Control v

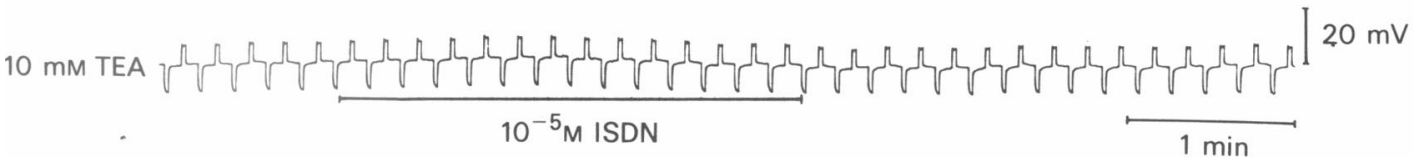

Figure 2 Effects of $10^{-5} \mathrm{M}$ isosorbide dinitrate (ISDN) on the membrane resistance and spike evoked by outward current pulses in the mesenteric artery and vein. In the presence or absence of $10 \mathrm{~mm}$ tetraethylammonium (TEA), the same intensity of inward and outward current pulses (pulse duration $2 \mathrm{~s}$ ) was alternately applied.

Control

$0.25 \mathrm{~Hz}$<smiles>C1CCCC1</smiles><smiles>C1=CCCCC1</smiles><smiles>[AlH2]</smiles><smiles>[AlH2]</smiles><smiles>[AlH2]</smiles><smiles>[AlH]=[V]</smiles><smiles>CCCC</smiles>

\section{$10^{-5} \mathrm{M}$ ISDN}

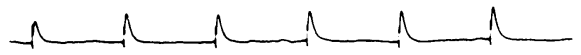

$0.5 \mathrm{~Hz}$
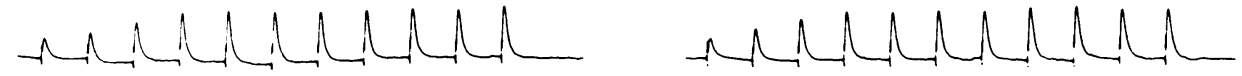

$1.0 \mathrm{~Hz}-\mathrm{MLCHCH}$

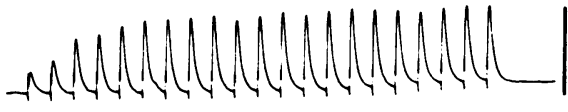
$20 \mathrm{mV}$

$10 \mathrm{~s}$

Figure 3 Effects of $10^{-5} \mathrm{M}$ isosorbide dinitrate (ISDN) on the excitatory junction potentials (e.j.ps) evoked from smooth muscle cell membranes. Three stimulus frequencies $(0.25 \mathrm{~Hz}, 0.5 \mathrm{~Hz}$ and $1.0 \mathrm{~Hz})$ were applied $(0.05 \mathrm{~ms}$ pulse duration and $50 \mathrm{~V}$ stimulus intensity). E.j.ps were recorded $10 \mathrm{~min}$ after application of ISDN. Before and after application of ISDN, e.j.ps were recorded from the same cell.

\section{Results}

\section{Effects of isosorbide dinitrate on the membrane potential and spike of smooth muscle cells in the mesenteric artery and vein}

Membrane potentials of the smooth muscle cells of rabbit mesenteric artery and vein were
$-71.3 \pm 2.1 \mathrm{mV} \quad(n=30)$ and $-64.2 \pm 2.3 \mathrm{mV}$ $(n=30)$, respectively. Applications of ISDN $\left(10^{-8} \mathrm{M}\right.$ $\left.-10^{-5} \mathrm{M}\right)$ did not modify the membrane potentials of smooth muscle membranes in either tissue $(-70.1 \pm 2.5 \mathrm{mV}, \quad n=20$, and $-63.1 \pm 2.7 \mathrm{mV}$, $n=20$, in smooth muscle cells of artery and vein, respectively).

Figure 1 shows the effects of $10^{-5} \mathrm{M}$ ISDN on the 
membrane potential of smooth muscle cells of artery $(a, b)$ and vein $(c, d)$ in the presence of various concentrations of $[K]_{o}(a, c)$ or noradrenaline $(\mathrm{NA} ; \mathrm{b}, \mathrm{d})$. Applications of excess concentrations of $[K]_{0}$ depolarized the membrane, dose-dependently in both tissues, yet the maximum slope of the $\mathrm{K}$-induced depolarization plotted on a log scale was steeper in the case of artery than that of the vein $(52 \mathrm{mV}$ and $47 \mathrm{mV}$ per tenfold increase in [K $]_{\mathrm{o}}$, respectively). The threshold concentration of NA required to produce depolarization was lower in the case of the vein $\left(10^{-7} \mathrm{M}\right.$ and $\left.5 \times 10^{-7} \mathrm{M}\right)$ and the depolarization induced by $10^{-5} \mathrm{M}$ was $-37.2 \pm 2.5 \mathrm{mV}(n=15)$ in the artery and $-28.3 \pm 2.8 \mathrm{mV}(n=15)$ in the vein. With application of $10^{-5} \mathrm{M}$ ISDN, the depolarization induced by application of excess concentrations of $[\mathrm{K}]_{\mathrm{o}}$ or NA was not modified, at any given concentration.

In the smooth muscle cell membrane of the rabbit mesenteric artery, the spike could be evoked by application of outward current pulses in the presence of $10 \mathrm{mM}$ tetraethylammonium (TEA). Figure 2 shows the effects of $10^{-5} \mathrm{M}$ ISDN on the spike generation in smooth muscle cells of the rabbit mesenteric artery. With application of $10 \mathrm{mM}$ TEA, the membrane was depolarized to $-63.2 \pm 3.2 \mathrm{mV}(n=15)$ and the membrane resistance was increased as determined from the amplitude of the electrotonic potential produced by application of a constant intensity inward current pulse (at $0.2 \mathrm{~mm}$ distance from the stimulating electrode; 1.9 times the control, $n=3$ ) and outward current pulses evoked the spike. When $10^{-5} \mathrm{M}$ ISDN was applied to the tissue, the evoked spike was gradually reduced in amplitude but was not totally abolished. The reduction in amplitude of the evoked spike was observed only with application of ISDN in concentrations above $10^{-5} \mathrm{M}$.

Figure 2 also shows the effects of ISDN on the membrane properties of smooth muscle cells of the mesenteric vein in the presence or absence of $10 \mathrm{~mm}$ TEA. The microelectrode was inserted into the cell $0.1 \mathrm{~mm}$ from the stimulating electrode. Alone, $10^{-5} \mathrm{M}$ ISDN modified neither the membrane potential nor the membrane resistance as estimated from the amplitude of the electrotonic potentials. When $10 \mathrm{mM}$ TEA was applied, the membrane was depolarized to $-52.1 \pm 2.7 \mathrm{mV},(n=15)$ and the membrane resistance was increased as measured from amplitude of the electrotonic potential (2.6 times the control, $n=3$ ), yet the spike was not evoked by application of outward current pulses. In the presence of $10 \mathrm{~mm}$ TEA, $10^{-5} \mathrm{M}$ ISDN did not modify either the membrane potential or the membrane resistance.

When perivascular nerve stimulation was applied to the tissue $(50 \mathrm{~V}$ intensity and $0.5 \mathrm{~ms}$ pulse duration), the membrane was transiently depolarized and repetitive stimulation gradually enhanced the amp- litude of depolarization. This depolarization was prevented by pretreatment with $10^{-7} \mathrm{M}$ TTX or $10^{-6} \mathrm{M}$ guanethidine, indicating that this depolarization is the excitatory junction potential (e.j.p.) due to release of NA from nerve terminals. Figure 3 shows the effects of $10^{-5} \mathrm{M}$ ISDN on the e.j.p. evoked by perivascular nerve stimulation with three different frequencies of stimulation $(0.25 \mathrm{~Hz}, 0.5 \mathrm{~Hz}$ and $1.0 \mathrm{~Hz}$ ). ISDN modified neither the initial amplitude of e.j.p. nor the facilitation process.

\section{Effects of isosorbide dinitrate on mechanical properties of mesenteric artery and vein}

Figure 4 shows the effects of ISDN on the NAinduced contractions evoked in the mesenteric artery and vein. Application of $10^{-5} \mathrm{M}$ NA produced oscillatory phasic contraction in both vessels. Pretreatment with ISDN in concentrations above $10^{-7} \mathrm{M}$ consistently inhibited the NA-induced contraction in the mesenteric vein, i.e. reduced the number and amplitude of phasic contractions as well as the tonic contraction. Increasing the concentration to $10^{-5} \mathrm{M}$ abolished the phasic contraction and only a low amplitude tonic contraction was evoked (Figure 4a). In case of the mesenteric artery, pretreatment with $10^{-5} \mathrm{M}$ ISDN had no effect on the phasic or tonic contractions, however, the onset of the phasic contraction was slightly delayed (Figure 4b).

Figure 5 shows the effects of ISDN on the Kinduced and NA-induced contractions in the mesenteric artery. The preparations were pretreated with $10^{-6} \mathrm{M}$ guanethidine and $10^{-7} \mathrm{M}$ TTX to prevent the release of NA by depolarization of nerve terminals during application of excess concentration of $[K]_{0}$. When $20.2 \mathrm{mM}[\mathrm{K}]_{\text {o }}$ was applied, a contraction was generated and increased concentrations of $[K]_{0}$ enhanced the amplitude of contraction, in a dosedependent manner. When $10^{-6} \mathrm{M}$ ISDN was applied, the amplitude of the $\mathrm{K}$-induced contraction was not affected. As shown in Figure 5a, the contraction was only slightly inhibited by $10^{-5} \mathrm{M}$ ISDN at any given concentration of $[\mathrm{K}]_{\mathrm{o}}$ (in $118 \mathrm{mM}[\mathrm{K}]_{\mathrm{o}} ; 0.86 \pm 0.08$ times the control, $n=4, P<0.05)$. NA also produced a contraction, the minimum concentration required being $3 \times 10^{-7} \mathrm{M}$; increasing concentrations of NA dose-dependently enhanced the contraction. ISDN $10^{-5} \mathrm{M}$ did not modify the contraction evoked by any given concentration of NA (Figure $5 b$ ).

Figure 6 shows the effects of ISDN on the contraction evoked by nerve stimulation or direct muscle stimulation. In the mesenteric artery, perivascular nerve stimulation produced a contraction associated with the generation of spikes on e.j.ps. Trains of more than 3 stimuli at $15 \mathrm{~Hz}, 0.55 \mathrm{~ms}$ pulse duration and $50 \mathrm{~V}$ intensity evoked a contraction (a). After pretreatment with $3 \times 10^{-6} \mathrm{M}$ ISDN, the evoked con- 


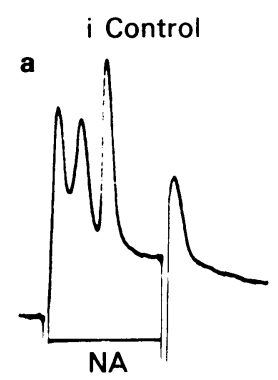

$$
\text { ii } 10^{-7} \mathrm{M} \text { ISDN }
$$

iii $10^{-6} \mathrm{M}$ ISDN

iv $10^{-5} \mathrm{M}$ ISDN
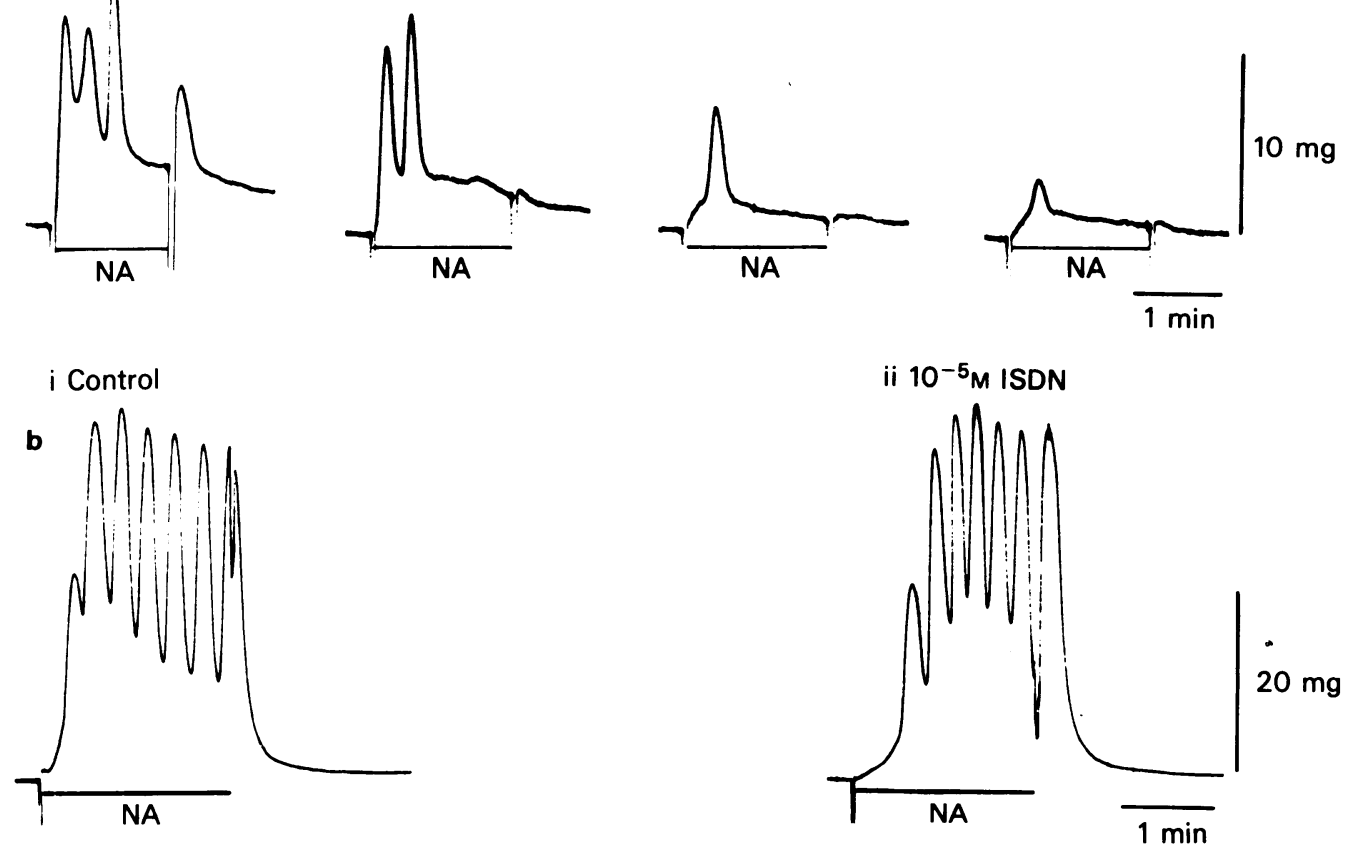

Figure 4 Effects of isosorbide dinitrate (ISDN) on the noradrenaline (NA)-induced contraction evoked in the mesenteric vein (a) and artery (b). (a) Effects of $10^{-7}-10^{-5} \mathrm{M}$ ISDN on the $10^{-5} \mathrm{M}$ NA-induced contraction in the mesenteric vein: (i) control; (ii-iv) applications of ISDN. (b) Effects of $10^{-5} \mathrm{M}$ ISDN on the $10^{-5} \mathrm{M}$ NA-induced contraction in the mesenteric artery: (i) control; (ii) application of ISDN).

traction was inhibited consistently $(n=6)$, yet the contraction evoked by direct muscle stimulation with trains at $10 \mathrm{~Hz}, 50 \mathrm{~ms}$ pulse duration and $50 \mathrm{~V}$ intensity in the presence of $10^{-6} \mathrm{M}$ guanethidine and $10^{-7} \mathrm{M}\left(n=8\right.$ in b) was not modified by $10^{-5} \mathrm{M}$ ISDN. The action of ISDN is only evident when the contraction is evoked by perivascular nerve stimulation.

On the other hand, in the mesenteric vein, ISDN $\left(10^{-6} \mathrm{M}\right)$ consistently inhibited the contraction evoked by various concentrations of $[\mathrm{K}]_{\mathrm{o}}$. As shown in Figure $7 a$ and $b$, four different concentrations of $[\mathrm{K}]_{\text {o }}$ were applied after pretreatment with three different concentrations of ISDN $\left(10^{-7} \mathrm{M}-10^{-5} \mathrm{M}\right)$. The $\mathrm{K}$-induced contraction was consistently reduced after applications of ISDN $\left(>10^{-6} \mathrm{M}\right)$. The effects of ISDN were also observed on the tonic contraction evoked by $55 \mathrm{~mm}[\mathrm{~K}]_{\mathrm{o}}$. Amplitudes of the phasic and tonic contractions evoked by $55 \mathrm{mM}[\mathrm{K}]_{\mathrm{o}}$ in the mesenteric vein were smaller than those evoked in the mesenteric artery. Application of $10^{-7} \mathrm{M}$ ISDN produced a transient contraction followed by a small relaxation of the mesenteric vein, and amplitudes of the relaxation induced by ISDN $\left(10^{-5} \mathrm{M}\right)$ were dosedependent, while $10^{-5} \mathrm{M}$ ISDN did not modify the tonic contraction evoked from the mesenteric artery, as shown in Figure 8. The continuous lines during the tonic contraction in Figure 8 are probable amplitudes of tonic contraction evoked in both vascular tissues.

\section{Effects of isosorbide dinitrate on the skinned muscles prepared from the mesenteric artery and vein}

Effects of ISDN on the Ca-induced contraction, and $\mathrm{Ca}$ accumulation into and release from stores were investigated in chemically skinned muscles from both the artery and vein. After skinning the tissue, various and increasing concentrations of $\mathrm{Ca}$ were applied to the tissue without washout. The minimum and maximal contractions evoked by free Ca were $10^{-7} \mathrm{M}$ and $10^{-5} \mathrm{M}$, respectively. The $\mathrm{pCa}$ (free $\mathrm{Ca}$ concentration)-tension relationships observed in cases of the mesenteric artery and vein were sigmoidal. As shown in Figure 9, the contractions evoked by $10^{-5} \mathrm{M} \mathrm{Ca}$ in skinned muscles in both tissues were consistently larger than the contraction evoked by $128 \mathrm{mM}[\mathrm{K}]_{\mathrm{o}}$ in the intact muscles. After the response to each concentration of $\mathrm{Ca}$ had reached a plateau, $10^{-5} \mathrm{M}$ ISDN was applied. ISDN did not modify the 

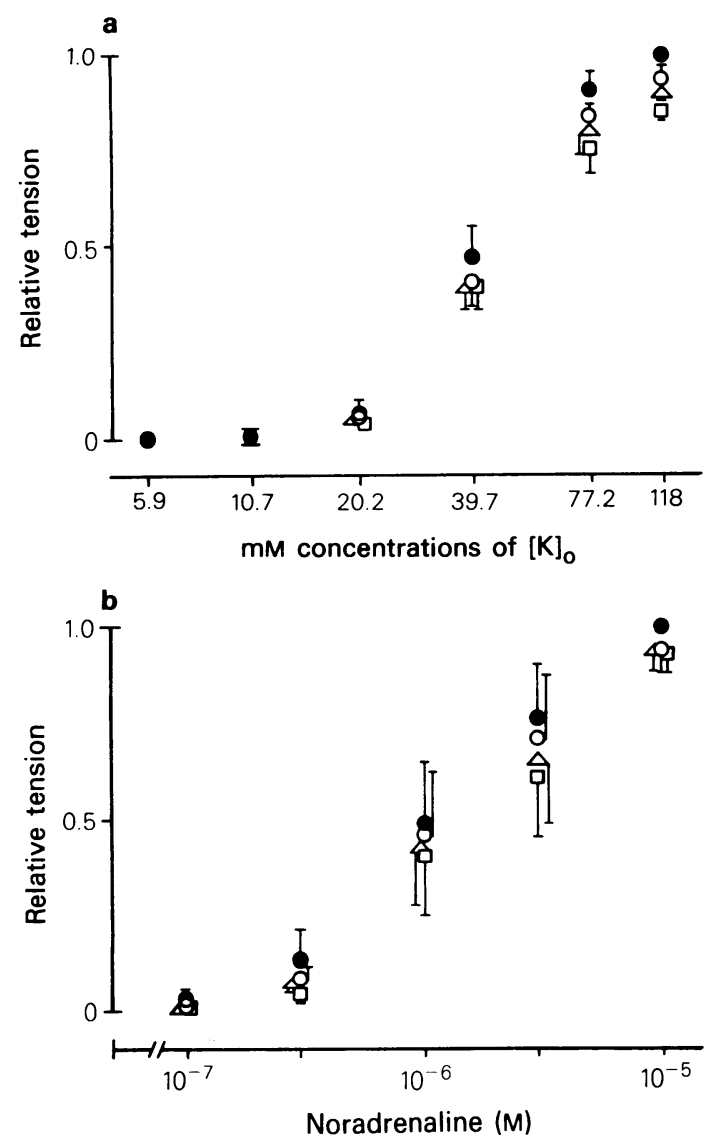

Figure 5 Effects of isosorbide dinitrate (ISDN) on the mechanical response evoked by applications of various concentrations of $[\mathrm{K}]_{\mathrm{o}}$ (a) or noradrenaline (NA) (b) in the mesenteric artery. (a) Effects of $10^{-6}(\mathrm{O}), 3 \times 10^{-6}$ $(\triangle)$ and $10^{-5}(\square) \mathrm{M}$ ISDN on the K-induced contraction; (O), control. $[\mathrm{K}]_{\mathrm{o}}(118 \mathrm{mM})$ induced contraction was taken as a relative tension of 1.0. Guanethidine and tetrodotoxin were present. Vertical bars indicate s.d. $(n=6)$. (b) Effects of $10^{-6}-10^{-5} \mathrm{M}$ ISDN on the NAinduced contraction (symbols as in (a)). NA $\left(10^{-5} \mathrm{M}\right.$ )induced contraction was taken as a relative tension of 1.0. Vertical bars indicate s.d. $(n=4)$.

contraction evoked by application of $\mathrm{Ca}$ in either the mesenteric artery or vein. This indicates that ISDN does not affect contractile proteins or calmodulin which activates the light chain phosphokinase of the myosin for triggering off the contraction.

Figure 10 shows the effects of ISDN on the $\mathrm{Ca}$ accumulation into and $\mathrm{Ca}$ release from stores in skinned muscles. After skinning the tissue, $10^{-6} \mathrm{M}$ Ca was applied for intracellular storage, the tissue was then rinsed with $10^{-4} \mathrm{M}$ EGTA-containing relaxant solution for a certain time until the tissue relaxed to the
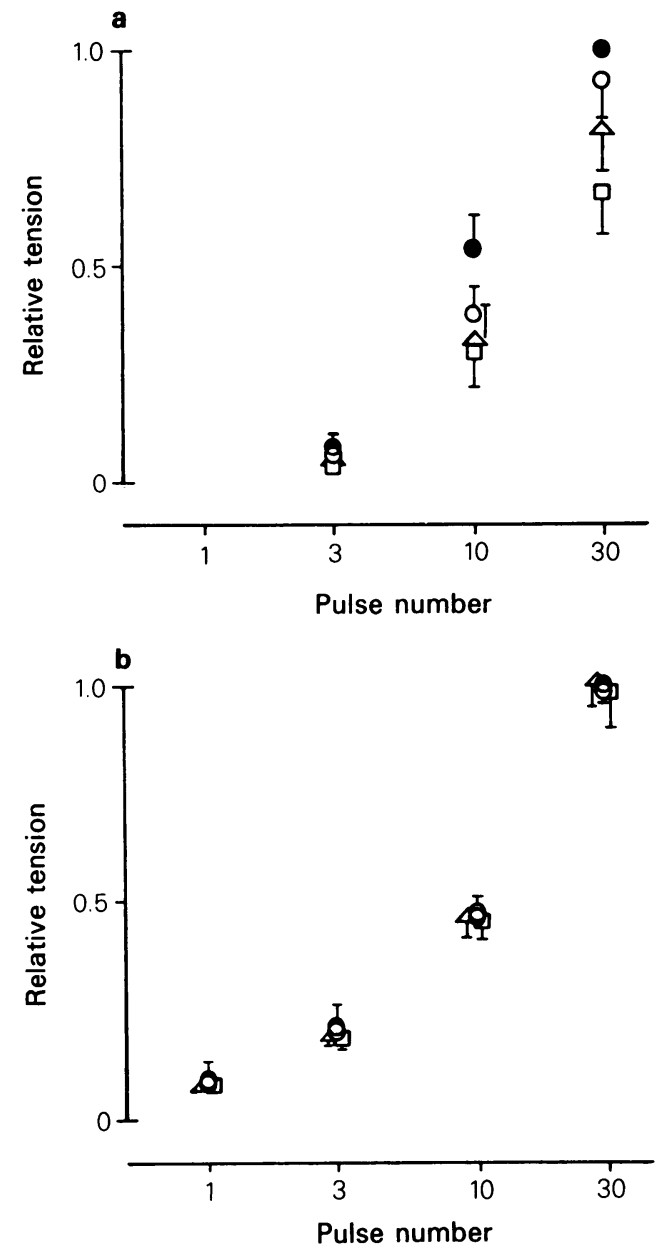

Figure 6 Effects of isosorbide dinitrate (ISDN) on the contraction evoked by perivascular nerve stimulation (a) or direct muscle stimulation (b). (a) Effects of $10^{-6}$ $(O), 3 \times 10^{-6}(\triangle)$ and $10^{-5}(\square) \mathrm{M}$ ISDN on the contraction evoked by perivascular nerve stimulation $(15 \mathrm{~Hz}$ in frequency, $0.55 \mathrm{~ms}$ in pulse duration, $50 \mathrm{~V}$ in stimulus intensity and 1-30 pulses were applied); ( $(0)$, control. Vertical bars indicate s.d. $n=6$. (b) Effects of $10^{-6}-10^{-5} \mathrm{M}$ ISDN on the contraction evoked by direct muscle stimulation in the presence of $10^{-6} \mathrm{M}$ guanethidine and $10^{-7} \mathrm{M}$ tetrodotoxin $(10 \mathrm{~Hz}$ in stimulus frequency, $50 \mathrm{~ms}$ in pulse duration, $50 \mathrm{~V}$ in intensity and 1-30 pulses were applied). Symbols as in (a). Vertical bars indicate s.d. $n=8$.

resting level; $10 \mathrm{mM}$ caffeine was then applied to evoke the contraction by releasing the stored $\mathrm{Ca}$. When $10^{-5} \mathrm{M}$ ISDN was applied during any of the above procedures, the resulting caffeine-induced contraction was unaffected in the artery and vein (Figure 10a and b). Therefore, ISDN does not seem 
a

i Control

ii $10^{-7} \mathrm{M}$ ISDN $1 \mathrm{~min}$
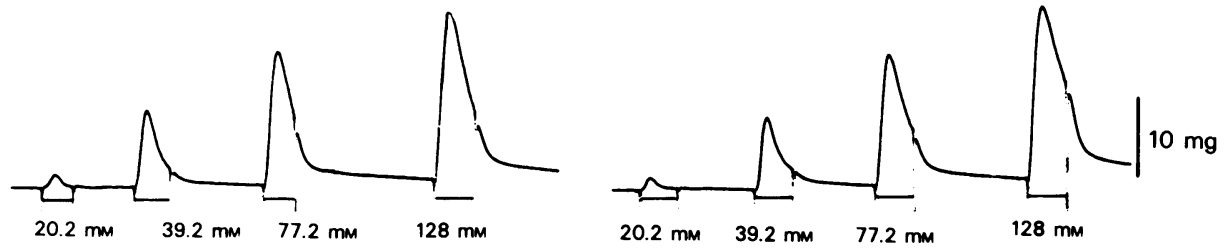

iii $10^{-6} \mathrm{M}$ ISDN

iv $10^{-5} \mathrm{M}$ ISDN

$1 \underline{\min }$
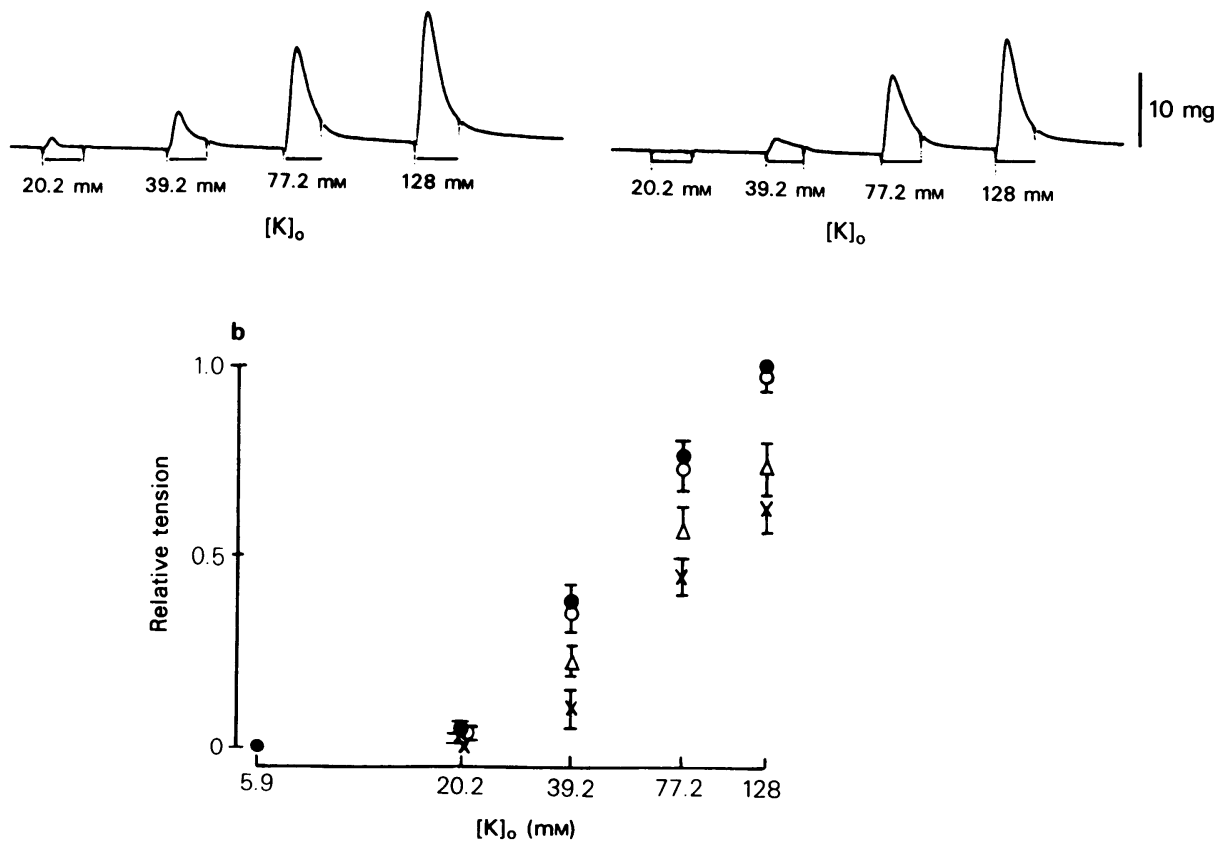

Figure 7 Effects of isosorbide dinitrate (ISDN) on the $\mathrm{K}$-induced contraction in the mesenteric vein. (a) (i)-(iv) effects of $10^{-7}-10^{-5} \mathrm{M}$ ISDN on the $20.2 \mathrm{mM}, 39.2 \mathrm{mM}, 77.2 \mathrm{mM}$ and $128 \mathrm{mM}$ [K] $]_{\mathrm{o}}$-induced contractions. ISDN was present throughout the experiments in a(ii)-a(iv); a(i), control. (b) effects of various concentrations of ISDN on the K-induced contraction: $10^{-7}(O), 10^{-6}(\triangle)$ and $10^{-5}(\times) \mathrm{M}$ ISDN; $(\bullet)$, control. The $128 \mathrm{mM}[\mathrm{K}]_{\mathrm{o}}$-induced contraction in the absence of ISDN was taken as a relative tension of 1.0. Vertical bars indicate s.d. $n=4-5$.

to modify the $\mathrm{Ca}$ accumulation into and $\mathrm{Ca}$ release from the stores in either of these tissues.

\section{Effects of isosorbide dinatrate on electrical and mechanical properties of smooth muscles of coronary artery}

The membrane potential of smooth muscle cells of the rabbit coronary artery was $-56.7 \pm 2.3 \mathrm{mV}$ $(n=20)$ and the cell was electrically quiescent. Application of $10^{-5} \mathrm{M}$ ISDN did not modify either the membrane potential or the membrane resistance, as measured from the amplitude of the electrotonic potential evoked by applications of the constant intensity of inward current pulses ( $2 \mathrm{~s}$ pulse duration). After pretreatment with $10 \mathrm{mM}$ TEA, the spike could be evoked by application of outward current pulses. Application of $10 \mathrm{mM}$ TEA depolarized the membrane, increased the input resistance and inhibited the rectification of the membrane, as measured from the amplitudes of electrotonic potentials evoked by alternately applied inward and outward current pulses with different intensities. When $10^{-5} \mathrm{M}$ ISDN was added during the generation of the spike by 
a
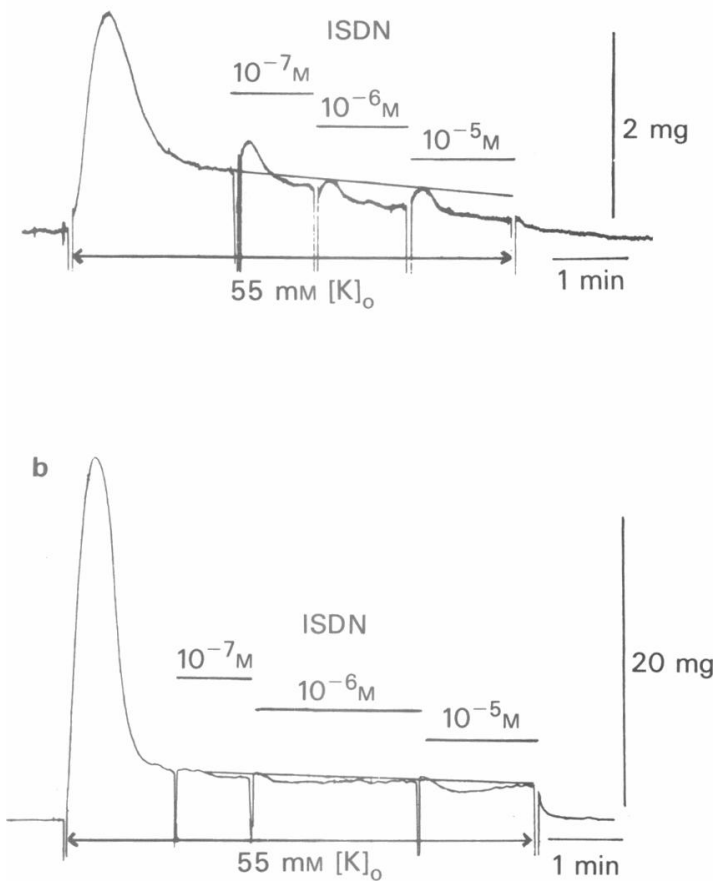

Figure 8 Effects of isosorbide dinitrate (ISDN) on the tonic response of the $55 \mathrm{mM}[\mathrm{K}]_{\mathrm{o}}$-induced contraction in the mesenteric vein (a) and artery (b); $10^{-7}-10^{-5} \mathrm{M}$ ISDN was successively applied.

application of outward current pulses in the presence of TEA, this agent had no effect on the amplitude and appearance of the spike (Figure 11).

In the rabbit coronary artery, the NA-induced contraction was much smaller than the acetylcholine (ACh)-induced contraction; therefore, the effects of ISDN were observed on the $\mathrm{K}$ - and $\mathrm{ACh}$-induced contractions.

When $3 \times 10^{-7} \mathrm{M} \mathrm{ACh}$ was applied to the tissue, phasic contractions were evoked from strips of coronary artery, similar to those evoked by application of $\mathrm{NA}$ to the mesenteric artery and vein. However, higher concentrations of $\mathrm{ACh}$ evoked large tonic contractions. Application of $2 \times 10^{-6} \mathrm{M}$ ISDN $2 \mathrm{~min}$ before application of $3 \times 10^{-7} \mathrm{M} \mathrm{ACh}$, delayed the onset of the contraction and reduced their amplitudes, while the same concentration of ISDN slightly prolonged the time required to reach the peak contraction but did not change the amplitude of tonic and phasic contractions evoked by $10^{-6} \mathrm{M}$ ACh (Figure $12 \mathrm{a}$ and $\mathrm{b}$ ). Concentrations of ISDN up to $10^{-5} \mathrm{M}$ reduced the amplitude of the contraction evoked by $3 \times 10^{-7} \mathrm{M} \mathrm{ACh}$ but no significant effect on the contraction evoked by $10^{-6} \mathrm{M} A C h$ was observed.
Phasic and tonic contractions evoked by the $39 \mathrm{mM}$ $[\mathrm{K}]_{\mathrm{o}}$ were not affected by treatment with $10^{-5} \mathrm{M}$ ISDN (Figure 12c). When $10^{-5} \mathrm{M}$ nitroglycerine was applied, the tonic response was markedly reduced (Figure 12d). Thus, the relaxation of the coronary artery induced by ISDN, was very weak in comparison to the action of nitroglycerine.

\section{Discussion}

Inorganic nitrites, organic nitrites and organic nitrates have been reported to increase coronary blood flow by decreasing the resistance of the coronary bed through direct vasodilatation. An organic nitrate, ISDN produces hypotensive effects in anaesthetized dogs (Krantz, Carr, Forman \& Ellis, 1939). Goldberg (1948) reported that this compound lowered arterial blood pressure in rabbit and man, and increased coronary flow in the rabbit isolated heart.

From clinical application, ISDN reportedly has long acting effects similar to those seen with nitroglycerine with regard to relief of anginal pain and myocardial ischaemia (Krantz, 1972; Willis, Russel \& Rackley, 1975); however, clinical studies of ISDN produced discrepant results. Some reports indicate that ISDN administered orally and sublingually is effective in reducing the frequency of angina attacks (Leslie, 1971), reducing left ventricle filling pressure in patients with heart failure (Klaus, Zaret, Pitt \& Ross, 1973) and reducing ST-segment depression during exercise (Gorman \& Evans, 1971). Other investigators found that treatment of angina with similar doses of ISDN did not significantly reduce the frequency of angina pain (Goldberg, Moran, Butterfield, Nemickas \& Bermudez, 1969), nor did it improve the exercise electrocardiogram (Livesley, Catley, Campbell \& Oram, 1973). Evidence for a cardiac effect of ISDN on isolated papillary muscles was obtained by Strauer (1973). This agent decreased coronary pressure and resistance after injection into the coronary artery (Case, Raven \& Crampton; 1964). Weisse, Senft, Khan \& Regan (1972), however, indicated that the only significant action of ISDN following coronary occlusion is a decrease in systemic blood pressure.

Meester \& Van Harn (1976) concluded that ISDN infusion following experimental coronary occlusion in anaesthetized dogs lowers systemic, cardiac and pulmonary blood pressures, decreases systemic resistance and has no significant effect on cardiac output, heart rate and stroke volume. Therefore, they concluded that ISDN may have minimal effects such as slight decrease in peripheral vascular resistance and systemic blood pressure. Fiedler \& Nitz (1981) reported that the actions of ISDN appear to depend on a decreased coronary resistance as the result of re- 
a

Intact muscle

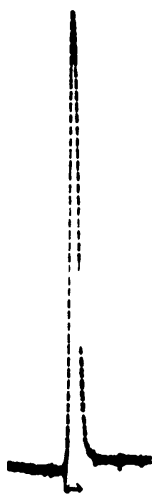

$128 \mathrm{~mm} \mathrm{~K}$

b

Intact muscle

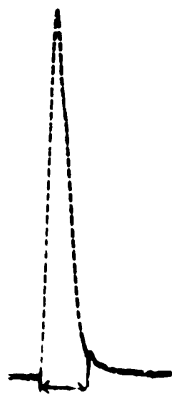

$128 \mathrm{~mm} \mathrm{~K}$

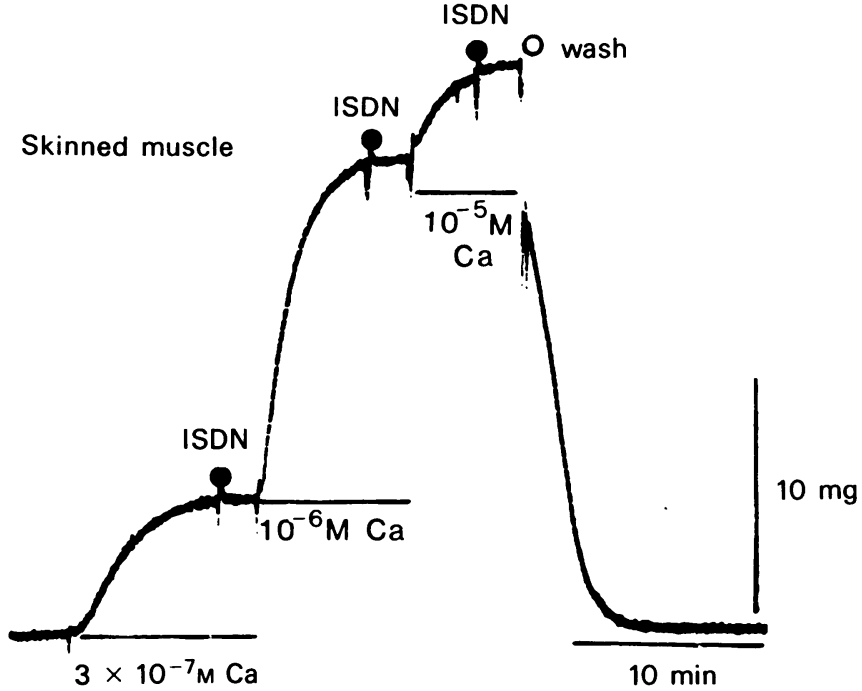

ISDN

Skinned muscle

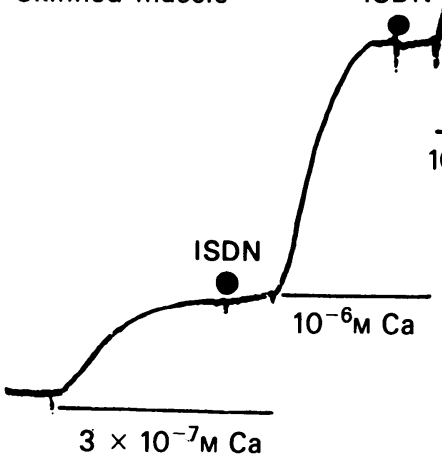

$10 \mathrm{mg}$

Figure 9 Effects of $10^{-5} \mathrm{M}$ isosorbide dinitrate (ISDN) on the Ca-induced contraction in skinned mesenteric artery (a) and vein (b). (a) Before application of $50 \mu \mathrm{g} / \mathrm{ml}$ saponin, $128 \mathrm{mM}[\mathrm{K}]_{\mathrm{o}}$ was applied to the intact tissue and after application of saponin various concentrations of free $\mathrm{Ca}\left(3 \times 10^{-7} \mathrm{M}-10^{-5} \mathrm{M}\right)$ were applied cumulatively. ISDN was added after the $\mathrm{Ca}$-induced contraction reached a steady level. (b) Effects of ISDN on the Ca-induced contraction of the mesenteric vein. The experimental procedures were the same as described in (a).

Figure 10 Effects of isosorbide dinitrate (ISDN) $\left(10^{-5} \mathrm{M}\right)$ on the Ca accumulation into and Ca release from the store site in the cell observed in skinned muscle preparations of the mesenteric artery (a) and vein (b). (a) After skinning the arterial tissue, $10^{-6} \mathrm{M} \mathrm{Ca}$ with $10^{-4} \mathrm{M}$ EGTA were applied to the tissue for $2 \mathrm{~min}$ (proc. 1) and after the tissue was rinsed with the relaxant solution (see Methods) for 2 min (proc. 2), $10 \mathrm{mM}$ caffeine was applied to the tissue (proc. 3). (i) Control; (ii) $10^{-5} \mathrm{M}$ ISDN was applied during proc. 1; (iii) $10^{-5} \mathrm{M}$ ISDN was applied during procs. 2 and 3. (b) Effects of ISDN on the Ca accumulation and $\mathrm{Ca}$ release in mesenteric vein. The experimental procedures in (i)-(iii) were the same as described in (a). 
a
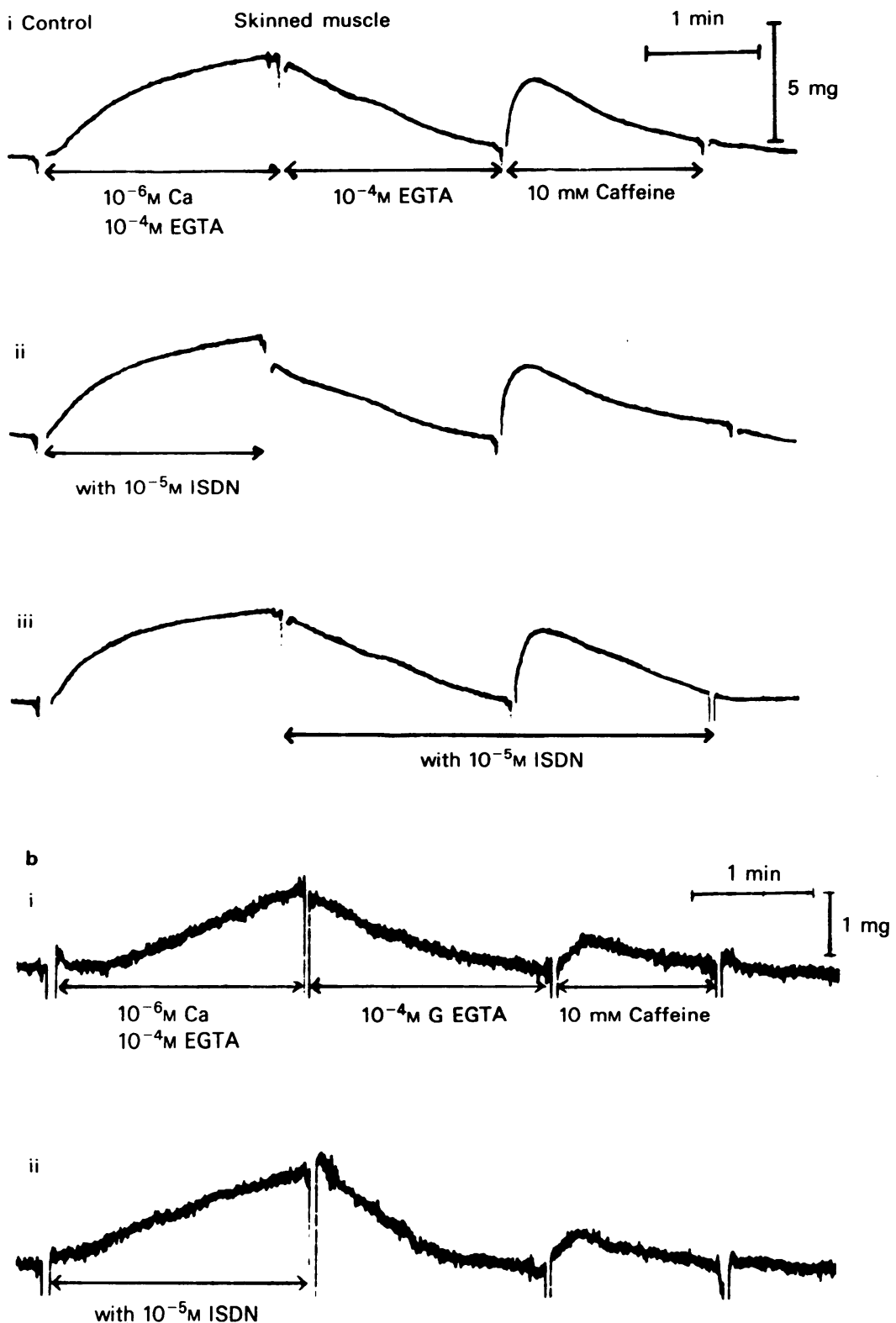

iii

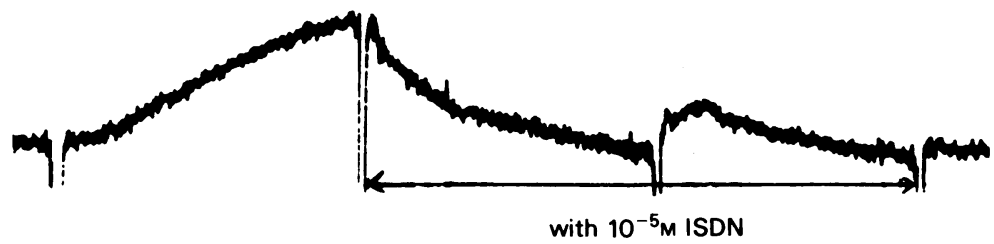




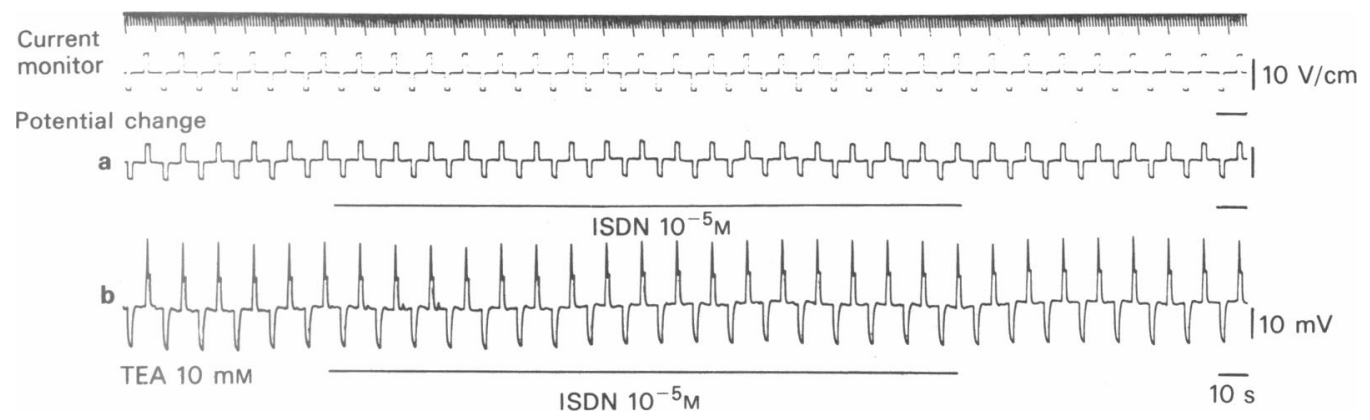

Figure 11 Effects of $10^{-5} \mathrm{M}$ isosorbide dinitrate (ISDN) on the membrane potential, membrane resistance and spike evoked in smooth muscle cell membranes of the coronary artery. (a) Effects of ISDN on the membrane in Krebs solution; 2 s pulse duration of inward and outward current pulses were applied alternately. (b) Effects of ISDN on the spike evoked by outward current pulses ( $2 \mathrm{~s}$ pulse duration) in presence of $10 \mathrm{mM}$ TEA. Inward and outward current pulses were applied alternately.

a

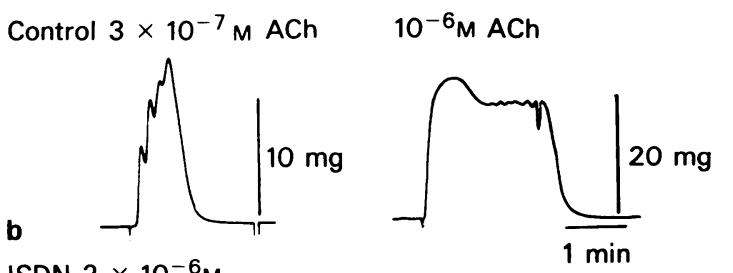

ISDN $2 \times 10^{-6} \mathrm{M}$

C
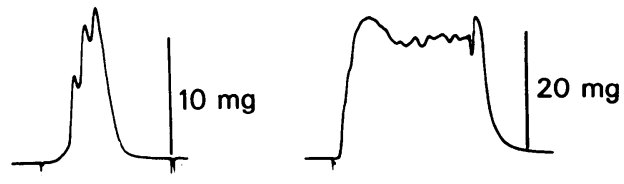

$39 \mathrm{mM}[\mathrm{K}]_{0}$

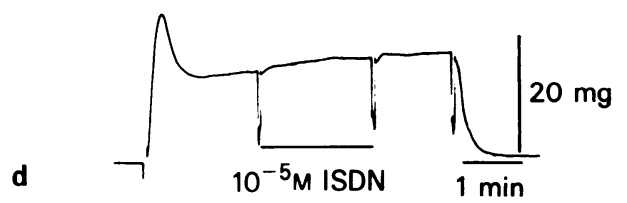

$39 \mathrm{~mm}[\mathrm{~K}]_{0}$

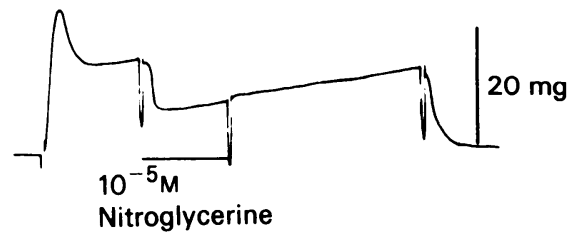

Figure 12 Effects of isosorbide dinitrate (ISDN) on the acetylcholine ( $\mathrm{ACh}$ )- and $\mathrm{K}$-induced contractions in the coronary artery: (a) $3 \times 10^{-7} \mathrm{M}$ and $10^{-6} \mathrm{M} \mathrm{ACh}$ induced contractions (control); (b) effects of $2 \times 10^{-6} \mathrm{M}$ ISDN on the $3 \times 10^{-7} \mathrm{M}$ and $10^{-6} \mathrm{M}$ ACh-induced contractions; (c) effects of $10^{-5} \mathrm{M}$ ISDN on the tonic response of the $39 \mathrm{mM}[\mathrm{K}]_{0}$-induced contraction; (d) effects of $10^{-5} \mathrm{M}$ nitroglycerine on the tonic contraction evoked by $39 \mathrm{mM}[\mathrm{K}]_{\mathrm{o}}$. duced ventricular volume and filling pressure, as a sequel of venous pooling, as have been described by Becker \& Pitt (1971).

The membrane potential and membrane resistance of smooth muscle cells, of both mesenteric artery and vein were not affected by application of $10^{-5} \mathrm{M}$ ISDN in resting conditions or after depolarization by application of excess concentrations of $[\mathrm{K}]_{\mathrm{o}}$ or NA. The spike evoked by outward current pulses after pretreatment with TEA in smooth muscle cells of the mesenteric artery was slightly reduced and as a consequence, the contraction evoked by direct muscle stimulation in the presence of TTX and guanethidine was slightly reduced, although $10^{-5} \mathrm{M}$ ISDN had little effect on the contraction evoked by direct stimulation in the absence of TEA. The amplitude and facilitation of e.j.ps evoked by perivascular nerve stimulation were not affected by ISDN. Similar observations were made upon the effect of nitroglycerine on e.j.ps (Itoh, Furukawa, Kajiwara, Kitamura, Suzuki, Ito \& Kuriyama, 1981).

On the other hand, ISDN inhibited the contraction of the mesenteric vein evoked by excess concentrations of $[\mathrm{K}]_{\mathrm{o}}$ or NA. The $\mathrm{K}$-induced contraction was composed of phasic and tonic components, and amplitudes of both components were inhibited by ISDN, this agent also inhibited the phasic contraction evoked by NA, i.e. the frequency of phasic contractions and tonic contraction were inhibited in a dosedependent manner by ISDN in concentrations over $10^{-7} \mathrm{M}$. The phasic contraction evoked by NA was postulated to be due to activation of the $\mathrm{Ca}$-induced Ca-release mechanism at the Castore in the cell, and the electrical events on the surface membrane probably do not contribute to generation of this phasic contraction (Itoh, Kuriyama Suzuki, 1983).

With regard to the pCa-tension relationship, the threshold and maximal concentrations of $\mathrm{Ca}$ for 
evoked contractions in skinned muscle tissues of both the mesenteric artery and vein were the same, thereby indicating that properties of calmodulin and contractile proteins in both tissues are similar. A slight difference was observed in the $\mathrm{Ca}$-accumulation and Ca-release process at the Ca store in the cells of both skinned muscle tissues. Application of $10^{-6} \mathrm{M} \mathrm{Ca}$ resulted in a caffeine-induced contraction which was smaller in the mesenteric vein than the mesenteric artery. ISDN $10^{-5} \mathrm{M}$ did not affect the pCa-tension relationships in either tissue. These effects were similar to the effect of nitroglycerine in skinned pig coronary artery (Itoh, Kajiwara, Kitamura \& Kuriyama, 1982).

When $10^{-5} \mathrm{M}$ ISDN was applied to skinned muscles with $10^{-6} \mathrm{M} \mathrm{Ca}$ or with $10 \mathrm{mM}$ caffeine, the amplitude of the caffeine-induced contraction was not affected. Therefore, the relaxation induced in the mesenteric vein by application of ISDN could not be explained by the results obtained in skinned muscles. Assuming that the response of the saponin-treated skinned muscle indicates an actual physiological responses, difference in the $\mathrm{Ca}$ extrusion process from the cell may play an important role in relaxation of the mesenteric vein as induced by ISDN, in comparison to that of the mesenteric artery.

In the rabbit coronary artery, the membrane potential and resistance were not affected by ISDN $\left(<10^{-5} \mathrm{M}\right)$, and the contraction evoked by various concentrations of $[\mathrm{K}]_{\mathrm{o}}(>29.7 \mathrm{mM})$ and the spike evoked by outward current pulses in the presence of TEA were not affected by ISDN, while the contrac- tion evoked by a low concentration of $\mathrm{ACh}$ $\left(3 \times 10^{-7} \mathrm{M}\right)$ was slightly inhibited by $10^{-5} \mathrm{M}$ ISDN. These actions of ISDN differ from those observed in the mesenteric vein. Furthermore, the action of ISDN on the coronary artery differed from that of nitroglycerine, i.e. nitroglycerine consistently inhibited the amplitude of contraction evoked by excess concentrations of $[\mathrm{K}]_{\mathrm{o}}$, electrical depolarization or NA in the porcine and canine coronary arteries (Ito $e t$ al., 1979; Iro, Kitamura \& Kuriyama 1980 a, b). In the rabbit coronary artery, the tonic response of the $\mathrm{K}$-induced contraction was inhibited by nitroglycerine but not by ISDN.

From the effects of ISDN observed from the mesenteric artery, vein and coronary artery, in vitro, the vasodilator action in the mesenteric vein is most obvious. Species differences are also observed in the ISDN action, i.e. in the porcine coronary artery, the contraction evoked by outward current pulses was slightly suppressed, in the presence or absence of spike generation, but this action of ISDN was weaker than that of nitroglycerine (unpublished observations). Judging from the action of ISDN on rabbit vascular tissues, this agent may relieve myocardial ischaemia by reducing the venous return of blood flow and the left ventricular end-diastolic pressure.

This work was partly supported by the grant of Ministry of Education (57440031, 57213031). We thank M. Ohara for reading the manuscript.

Isosorbide dinitrate was kindly provided by the Eisai Pharmaceutical Company, Tokyo.

\section{References}

ABE, Y. \& TOMITA, T. (1968). Cable properties of smooth muscle. J. Physiol., 196, 87-100.

BECKER, L. \& PITT, B. (1971). Regional myocardial blood flow, ischemia and antianginal drugs. Ann. Clin. Res., 3, 353-358.

BRUNTON, T.L. (1867). Use of nitrate of amyl in angina pectoris. Lancet, ii, 97-98.

CASE, R.B., RAVEN, R.B. \& CRAMPTON, R.S. (1964). Benign coronary dilating action of nitroglycerin and isosorbide dinitrate. Circulation, 30, (Suppl. III), 58.

FIEDLER, V.B. \& NITZ, R.E. (1981). Effects of molsidomine, nitroglycerin, and isosorbide dinitrate on the coronary circulation, myocardial oxygen consumption, and haemodynamics in anaesthetized dogs. NaunynSchmiedebergs Arch. Pharmac., 317, 71-77.

GOLDBERG, L. (1948). Pharmacological properties of sorbide dinitrate. Acta physiol. scand., 15, 173-187.

GOLDBERG, A.N., MORAN, J.F., BUTTERFIELD, T.K., NEMICKAS, R. \& BERMUDEZ, G.A. (1969). Therapy of angina pectoris with propranolol and long-acting nitrates. Circulation, 40, 847-853.

GORMAN, P.A. \& EVANS, J.M. (1971). The effects of chewa- ble isosorbide dinitrate in coronary insufficiency. A report on exercise electrocardiograms in 13 patients. Med. Ann. Dist. Columbia, 40, 235-238.

ITO, Y., KITAMURA, K. \& KURIYAMA, H. (1979). Effects of acetylcholine and catecholamines on the smooth muscle cell of porcine coronary artery. J. Physiol., 294, 595-611.

ITO, Y., KITAMURA, K. \& KURIYAMA, H. (1980a). Actions of nitroglycerine on the membrane and mechanical properties of smooth muscles of the coronary artery of the pig. Br. J. Pharmac., 70, 197-204.

ITO, Y., KITAMURA, K. \& KURIYAMA, H. (1980b). Nitroglycerine and catecholamine actions on smooth muscle cells of the canine coronary artery. J. Physiol., 309, $171-184$.

ITOH, T., FURUKAWA, K., KAJIWARA, M., KITAMURA, K., SUZUKI, H., ITO, Y. \& KURIYAMA, H. (1981). Effects of 2-nicotinamidoethyl nitrate on smooth muscle cells and on adrenergic transmission in the guinea-pig and porcine mesenteric arteries. J. Pharmac. exp. Ther., 218, 260-270.

ITOH, T., KAJIWARA, M., KITAMURA, K. \& KURIYAMA, H. 
(1982). Roles of stored calcium on the mechanical response evoked in smooth muscle cells of the porcine coronary artery. J. Physiol., 322, 107-125.

ITOH, T., KURIYAMA, H. \& SUZUKI, H. (1981). Excitationcontraction coupling in smooth muscle cells of the guinea-pig mesenteric artery. J. Physiol., 321, 513-535.

ITOH, T., KURIYAMA, H. \& SUZUKI, H. (1983). Difference and similarities in noradrenaline- and caffeine-induced mechanical response in the rabbit mesenteric artery. $J$. Physiol., (in press).

KLAUS, A.P., ZARET, B.L., PITT, B.L. \& ROSS, R.S. (1973). Comparative evaluation of sublingual long-acting nitrates. Circulation, 48, 519-525.

KRANTZ, J.C., Jr. (1972). Action and nomenclature of nitroglycerin and nitrate esters. Am. J. Cardiol., 29, 436-438.

KRANTZ, J.C., Jr (1975). Historical background. In Organic Nitrates. Handbuch der Experimentellen Pharmakologie, ed. Needleman, P., Vol. 40, pp. 1-12. Berlin, Heidelberg, New York: Springer-Verlag.

KRANTZ, J.C., Jr., CARR, C.J., FORMAN, S.E. \& ELLIS, F.W. (1939). Alkyl nitrates. III. A pharmacologic study of new series of organic nitrates. J. Pharmac. exp. Ther., 67, 187-190.

LESLIE, R.E. (1971). A ten-year reevaluation. Nitroglycerin and isosorbide dinitrate in coronary insufficiency. Texas Med., 67, 95-98.

LIVESLEY, B., CATLEY, P.F., CAMPBELL, R.C. \& ORAM, S. (1973). Double-blind evaluation of verapamil, propranolol and isosorbide dinitrate against a placebo in the treatment of angina pectoris. Br. med. J., 1, 375-378.

MACKENZIE, J.E. \& PARRATT, J.R. (1977). Comparative effects of glyceryl trinitrate on venous and arterial smooth muscle in vitro; relevance to antianginal activity. Br. J. Pharmac., 60, 155-160.

MEESTER, W.D. \& VAN HARN, G.L. (1976). The effect of isosorbide dinitrate following experimental coronary occlusion. Am. Heart J., 92, 217-222.

MURRELL, W. (1879). Nitroglycerin as a remedy for angina pectoris. Lancet, i, 80-81.

NEEDLEMAN, P. \& JOHNSON, E.M., Jr. (1973). Mechanism of tolerance development to organic nitrates. J. Pharmac. exp. Ther., 184, 709-715.

PARKER, J.O. (1972). The effect of ischaemia on myocardial function. In The Effect of Acute Ischaemia on Myocardial Function. ed. Oliver, M.F., Julian, D.G. \& Donald, K.W. pp. 288-305. Edinburgh: Churchill Livingstone.

PARRATT, J.R. (1974). Pharmacological approaches to the therapy of angina. In Advances in Drug Research. ed. Simmonds, A.B., Vol.9, pp. 103-134. London; Academic Press.

PARRATT, J.R. (1975). Recent advances in the pathophysiology and pharmacology of angina. Gen. Pharmac., 6, 247-251.

STRAUER, B.E. (1973). Isosorbide dinitrate: Its action on myocardial contractility in comparison with nitroglycerin. Int. J. clin. Pharmac., 8, 30-36.

VATNER, S.F. \& HEYNDRICKX, G.R. (1975). Mechanism of action of nitroglycerin: coronary, cardiac and systemic effects. In Handbuch der Experimentellen Pharmakologie, ed. Needleman, P., Vol. 40, pp. 131-161. Berlin, Heidelberg, New York: Springer-Verlag.

WEISSE, A.B., SENFT, A., KHAN, M.I., \& REGAN, T.J. (1972). Effect of nitrate influsions on the systemic and coronary circulations following acute myocardial infarction in the intact dog. Am. J. Cardiol., 30, 362-370.

WILLIS, W.H., RUSSEL, R.O., JR. \& RACKLEY, C.E. (1975). Nitrates and nitrites in the treatment of Coronary artery disease. In Current Cardiovascular Topics, Vol. 1. ed. Donoso, E. pp. 157-164. Stuttgart: Thieme.

(Received December 21, 1982. Revised February 23, 1983.) 